\title{
The Relationship Between Lexis and Reading Comprehension:
}

\section{A Review}

\author{
Nayibe Rosado ${ }^{1}$ \& Keiby G. Caro ${ }^{1,2}$ \\ ${ }^{1}$ Universidad del Norte, Puerto Colombia, Colombia \\ ${ }^{2}$ Universidad del Atlántico, Puerto Colombia, Colombia \\ Correspondence: Nayibe Rosado, Instituto de Idiomas, Universidad del Norte, Puerto Colombia, Atlántico, Km 5 \\ Via Puerto Colombia, Colombia. Tel: 57-300-814-7185. E-mail: nrosado@uninorte.edu.co
}

Received: August 1, 2018 Accepted: October 14, 2018 Online Published: October 17, 2018

doi: 10.5539/elt.v11n11p136 URL: http://doi.org/10.5539/elt.v11n11p136

\begin{abstract}
It has been commonly reported by teachers and learners the strong and positive relationship between lexis and reading comprehension. This claim has been usually grounded on experience. In consequence, this paper attempts to find research-based evidence to support the connection between lexis and reading comprehension. To do this, a review of 128 studies was conducted using a set of criteria, after which thirteen studies were selected and screened to look for specific patterns. Salient themes emerged from the analysis: lexical coverage, direct instruction, lexical knowledge (breadth and depth), incidental and intentional learning and receptive and productive lexical knowledge. The analysis supports the connection between lexis and reading comprehension not only in EFL, but also in ESL and L1 contexts. In line with it, the research suggests that teachers should focus on systematic lexis instruction since it aids learners to increase both lexical knowledge and reading comprehension gains.
\end{abstract}

Keywords: lexis, lexical knowledge, reading comprehension, research studies

\section{Introduction}

The increasing interest in foreign language learning and the recent linguistic research have taken lexis to a position of importance and acknowledgment (Alemi \& Tayebi, 2011). For a long time, lexis instruction had been given little attention from teachers and neglected in research studies (Decarrico, 2001; Ketabi \& Hashemi, 2011; Moir \& Nation, 2008; Nation, 1990; Zimmerman, 1997). To this regard, Shen (2003) explained that "In the early 1980s, there was severe criticism of the neglect of vocabulary research" (p. 188) which had an incidence in the increasing number of studies addressing lexis in the last three decades of the twentieth century (Arnaud \& Bejoint, 1992; Barcroft, 2004; Carter \& McCarthy, 1988; Read, 2000; Schmitt, 1997; Sprenger, 2013). Research in these decades addressed different topics including “... student needs, teaching techniques, learner strategies, and incidental learning" (Folse, 2004, p. v).

The new investigations placed lexis research into a privileged position (Jiménez, 2002), stimulating the interest of researchers to review the scholarship during that time. In 1993, Raffaella Maiguashca a teacher and researcher in York University made a review where she highlighted the trends in lexis research and classified them into five specific areas: specialized bibliographies, lexis acquisition, lexis teaching, course materials, and lexicography. Eleven years later, Bogaards and Laufer (2004, p. vii) reported eleven areas: the construct of lexical knowledge; the relationship between lexical knowledge and language proficiency, predominantly on reading; the role of word frequency in lexis learning; task effect on learning; the use of dictionaries; interactive tasks; explicit versus implicit learning; incidental versus intentional learning; learning new words versus learning new meanings of acquired words; patterns of lexis development over time; strategies used by learners to comprehend and learn new lexical items, and testing lexical knowledge: breadth and depth, receptive and productive.

This review focuses on the second theme reported by Bogaards and Laufer (2004): the relationship between lexis and reading performance. Schmitt, Jiang and Grabe (2011) in a study about this relationship stated that "in general, research is increasingly demonstrating what practitioners have always known: that it takes a lot of vocabulary to use a language well" (p. 27). The primary motivation in this review is to support with empirical data from scientific studies teachers' intuitive or practice-driven belief of the dialectic relationship between students' reading comprehension and their lexis. 


\section{Importance of This Review}

Lexis is pivotal in language learning and development, especially in its relationship with reading as the skill that grants access to knowledge (Groux, 2015). Teachers oftentimes complain about the limited reading comprehension performance evidenced by their learners and ascribe it either to the lack of reading comprehension strategies in L1 or to the lack of the reading skill competence as such. Chall and Jacobs (2003) concluded that learners without adequate and steady lexis growth can undergo serious reading comprehension problems. Some research has already demonstrated that readers' ability to understand what they read is strongly connected to their lexical knowledge (Blachowicz, Fisher, Ogle, \& Watts-Taffe, 2006; Davis, 1944, 1968; Terman, 1916). Learners seem also aware of this connection as reported by Kameli and Bin Baki (2013) when referring to text complexity and its impact on reading comprehension: "Indeed, ESL/EFL readers frequently stated lack of sufficient word understanding as one of the major barriers to content comprehension so vocabulary load is a very important cue of text complexity" (p. 85).

Shen (2008) considered the relationship between lexis and reading as "complex and dynamic" (p. 135). Recent studies tackling this relationship (Joshi, 2005; Manyak \& Bauer 2009; Ricketts, Nation \& Bishop, 2007; Zhang \& Anual, 2008) evidenced that as learners gradually progress in reading and delve into the topics, they require to expand their lexis and get involved in multiple comprehension processes to grasp the meaning of the texts they are exposed to. This process is even more challenging when reading is developed in L2 in initial stages when vocabulary knowledge is nonexistent in the target language.

Some models, proposed by researchers, attempt to explain the relationship between lexical knowledge and reading comprehension performance. Among them, Anderson and Freebody (1981) established this relationship in three levels: "instrumentalist", "aptitude" and "knowledge". The first one refers to the level of lexis knowledge a reader needs to possess to enable reading comprehension; the second, to the acquired or natural skill for learning and the last, to the world knowledge required to understand a particular topic. The interaction among these three aspects can boost the levels of reading comprehension and performance; therefore, it is suggested that EFL teachers teach lexis including aspects such as form, meaning, pronunciation, grammar, collocation, etc., so that learners can develop the necessary lexical size and depth to gain reading comprehension (Apthord et al., 2012; Bauman et al., 2002; Caro \& Rosado, 2017; Graves, 2000; Matsuoka \& Hirsh, 2010; Stahl, 1983).

For learners to develop their lexis systematically, it is necessary for teachers to implement a multifaceted approach. Alemi and Tayebi, (2011) recommended three approaches to attain that: "1) Incidental learning; 2) Explicit or intentional instruction; and 3), Independent strategy development" (p. 82). Incidental refers to learning lexis as a result of engaging in other activities, without the specific intention to acquire it (Hulstijn, 2003). Explicit or intentional instruction deals with the direct intervention in class to train and explain learners how they can gain lexis; for instance, by using lexical learning strategies. This approach is mostly focused on EFL beginners who need a great deal of support from teachers since their reading comprehension skills are limited due to their also limited lexical knowledge (Hunt \& Beglar, 1998). Independent strategy development refers to training learners to become autonomous in lexis learning strategies. The literature suggests that learners need to receive sufficient learning strategy training to discover the strategies that best suit them (Ellis \& Sinclair, 1989; Chamot, 1987; Oxford, 1990; Nation, 2001). It also highlights the effect that lexis learning strategies has on the process a learner can undergo to acquire lexical items influencing student's proficiency level (Farhady, 2006; Jiménez, 2003) as well as learners' agency (Schmitt, 1997). In sum, the use and appropriateness of a multifaceted approach could help learners develop lexis and become more aware of lexis development as a lifelong learning process.

\section{Methodology}

For this review, we used a qualitative document analysis method based on a priori criteria and followed the procedures from the National Reading Technical Assistance Center (NRTAC, 2010) to identify the body of studies to be included, namely, "searching subject indices and citations, browsing, and footnote chasing" (White 1994, cited by NRTAC, 2010, p. 3). Major online database systems (EBSCO, ERIC and PROQUEST) were searched to get access to appropriate studies between the years 2000 to 2017. The keywords used for the search were "vocabulary instruction", "vocabulary teaching", "vocabulary research" and "vocabulary and reading performance". The term vocabulary was used instead of lexis for this search because most of the articles make reference to that. The search yielded 159 studies in total. Of this list, 31 were discarded for being literature reviews. The remaining 128 were screened, based on the ensuing criteria:

- The study must come from a scientific journal.

- Research studies must be about lexis and reading. Topics were identified from the titles, the abstracts, the keywords and from browsing the article in general. 
- $\quad$ The study must have been published between 2000 and 2017.

- The study must involve students as participants.

- The study must involve a lexis instruction intervention or treatment.

After the screening, the number of studies reduced to 30. In this reduced set, information such as the target group (participants, type of population, EFL, ESL or native), and the location of the study was also identified. Once the target articles were thoroughly examined, a final sample of 13 was chosen for this review. The findings will be presented in the section below and the term vocabulary will be replaced by lexis and lexical to make it coherent with the authors epistemological positioning.

\section{Findings}

In general, the studies outlined below show relationships between lexical knowledge and reading in first and second language (Laufer, 1991). We confirmed what Krashen (2013) posited, “... vocabulary is acquired as a result of receiving comprehensible input... this means reading" (p. 29).

As a whole, there are publications on the established relationship between lexis and reading comprehension, especially in issues published in 2016 and 2017. There seems to be interest in providing guidelines or models of lexis development through reading to the academic community. In addition, there are studies about tests administered to gauge the learners' reading progress, studies that used questionnaires to know more about lexical development and some others related to word-meaning instructional activities that promote deep processing (Manyak et al, 2014). Table 1 below lists the 13 studies reviewed in chronological order:

Table 1. Studies meeting criteria of the relationship between lexical knowledge and reading comprehension

\begin{tabular}{lll}
\hline Study & Topic & \\
\hline $\begin{array}{l}\text { 1. Unknown vocabulary density and reading } \\
\text { comprehension (Hu \& Nation, 2000) }\end{array}$ & $\begin{array}{l}\text { Relationship between lexical coverage and } \\
\text { reading comprehension }\end{array}$ & \\
\hline $\begin{array}{l}\text { 2. Investigating the relationship between } \\
\text { vocabulary knowledge and academic reading }\end{array}$ & $\begin{array}{l}\text { Lexis knowledge and academic reading } \\
\text { performance }\end{array}$ & \\
performance: an assessment perspective (Qian, & & \\
2002) & & \\
\hline $\begin{array}{l}\text { 3. At what rate do learners learn and retain new } \\
\text { vocabulary from reading a graded reader? }\end{array}$ & $\begin{array}{l}\text { Lexis acquisition, graded readers, extensive } \\
\text { (Waring \& Takaki, 2003) }\end{array}$ & \\
\hline $\begin{array}{l}\text { 4. Fostering the development of vocabulary } \\
\text { knowledge and reading comprehension through } \\
\text { contextually-based multiple meaning } \\
\text { vocabulary instruction (Ron \& Stage, 2007) }\end{array}$ & & \\
\hline
\end{tabular}

5. The effect of lexical coverage on L2 reading Lexical coverage and reading comprehension (Prichard \& Matsumoto, 2011)

6. Incidental acquisition of vocabulary by Incidental lexis trough reading reading (Ponniah, 2011)

7. Using the MoodleReader as an extensive Incidental lexis and extensive reading reading tool and its effect on Iranian EFL students' incidental vocabulary learning (Alavi \& Keyvanshekough, 2012)

8. The Impact of Vocabulary Knowledge Level
on EFL Reading Comprehension (Kameli \&
Bin Baki, 2013)




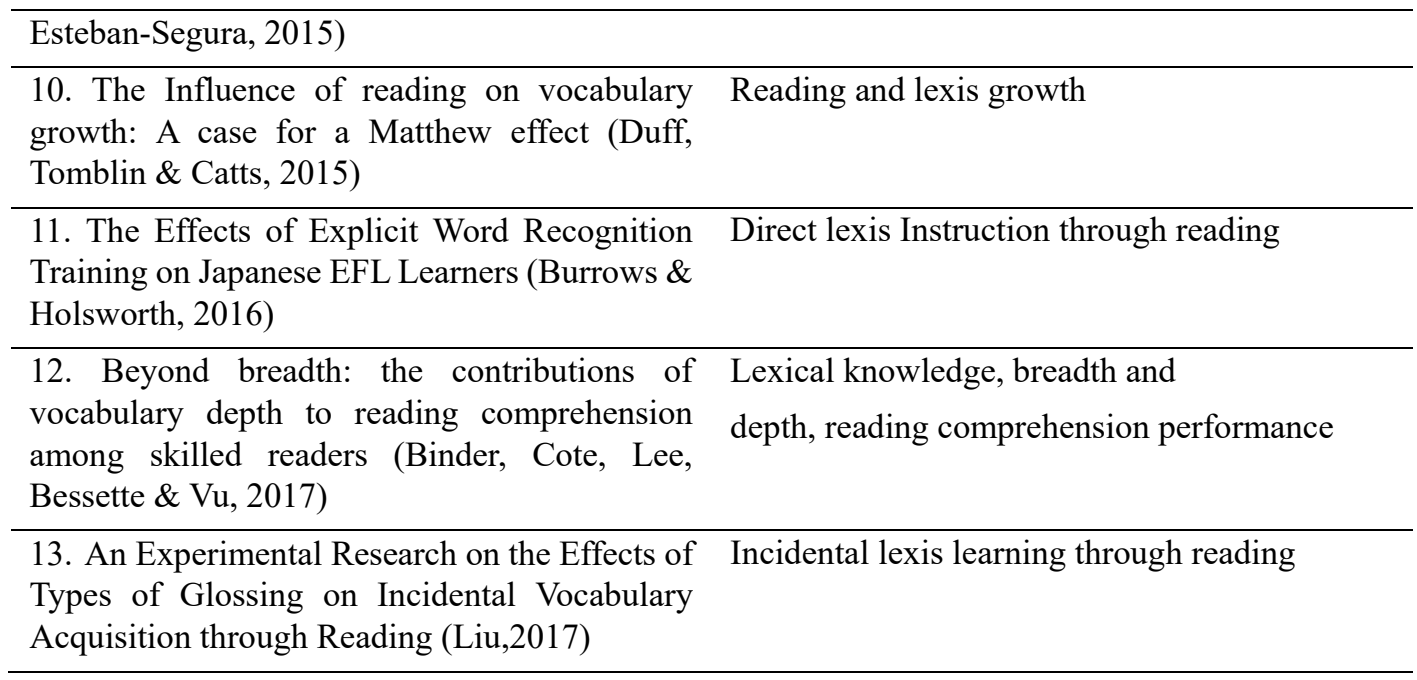

Once the analysis was done, the following recurrent themes emerged, in which researchers connected reading with lexis development: lexical coverage, direct instruction, lexical knowledge (breadth and depth), incidental and intentional learning, and receptive and productive lexical knowledge. Each theme with its corresponding studies and discussions are presented as follows:

\subsection{Lexical Coverage}

Lexical coverage also known in the literature as lexical threshold (West, 1926; Laufer, 1989, 1992) has to do with the percentage of lexical items a person should know from a written text, which allows him or her to comprehend most of what is being read. Lexical coverage can only be developed if reading takes place; the sole use of reading strategies cannot replace the lack of lexis. In fact, authors such as Schoonen, Hulstijn and Bossers (1998) highlight that the L1 reading strategies transfer does not suffice if the language proficiency is limited. There are two studies related to lexical coverage.

$\mathrm{Hu}$ and Nation (2000) attempted to determine the percentage of coverage (lexical items known in a text) for learners to read a text without lexical problems and gain unassisted reading comprehension from it. In order to prove that, a 673-word story was selected and four versions of it were laid out. The researchers replaced a percentage of the low frequency lexical items with nonsense ones as depicted in table 2 .

Table 2. Percentage of the replaced low frequency lexical items

\begin{tabular}{lll}
\hline Coverage & \# Of nonsense & Percentage \\
\hline $100 \%$ & 0 & 0 \\
$95 \%$ & 32 & 1 in 20 \\
$90 \%$ & 63 & 1 in 10 \\
$80 \%$ & 127 & 1 in 5 \\
\hline
\end{tabular}

The target group was assigned to one of the four versions randomly. In total, 66 participants partook in this experiment, 17 of them read the 100\% version, 17 the 95\%; after the reading, a Vocabulary Levels Test (VLT) and two reading comprehension tests (the multiple choice test and the cued written recall test) were administered to each one of them. The results showed overly that the density of unfamiliar lexical items has a toll on reading comprehension. To overcome this, the authors recommended that learners count on $98 \%$ of lexical coverage so as to comprehend any written text without assistance.

Prichard and Matsumoto (2011) carried out a study on the effect that lexical coverage had on reading comprehension. 103 lower-intermediate to intermediate first-year university Japanese students were given a short authentic academic text (650 words) to measure their ability to comprehend it. These students were given a list of 71 words and asked to write a definition in their native language. This was done through a comprehension test. The results are consistent with the studies encountered in Hu and Nation's and Laufer's (1989), that is, a 97\% coverage 
is estimated for adequate comprehension gain.

Based on the aforementioned studies, the reading strategies per se are not only the key to success in reading comprehension, a combination of learners' motivation and commitment, among other factors, are also required. For this reason, teachers ought to be aware of this and make the corresponding adjustments in both the curricula and classroom practices incorporating the lexis instruction strategies such as selecting the reading material with different degree of difficulty (Carver, 1994). The Texas Reading Initiative (2002) identified five effective lexis instruction strategies to be considered:

1) Promote extensive reading

2) Enrich learners' environment with high-quality oral language

3) Teach independent lexical items-learning strategies and modeling.

4) Raise lexical items awareness

5) Teach meaning of lexical items directly

The strategies outlined above can help learners develop their lexis and reach their necessary lexical coverage to gain reading comprehension in the long run.

\subsection{Direct Instruction}

Three studies are on lexical development through direct instruction. According to Sedita (2005), this method refers to “...teaching specific words, such as pre-teaching vocabulary prior to reading a selection. " and " ...the analysis of word roots and affixes (suffixes and prefixes)" (p. 2). One distinct element of direct instruction is the repeated exposure of the taught lexical items in contextualized settings to support their learning.

The first study in this group is Waring and Takaki's (2003). They report an experiment with fifteen Japanese university female students aged 19 to 21 years whose level of English ranged from lower-intermediate to above. They chose a graded reader Level 1 containing 400 headwords and substituted some of the words with unreal ones. The target group was asked to read it and was tested without any previous instruction. The results were positive at the very beginning, but three months later they dropped abruptly due to the artificiality of the words.

The second study done by Ron and Stage (2007) gauged the effectiveness of contextually-based meaning vocabulary instruction considering the L1 lexical knowledge and reading performance in 283 primary school students. They were given pre- and post-tests on reading comprehension. Based on the results, the researchers formed two groups: one experimental receiving contextually-based multiple meaning lexis instruction along with their language arts classes. The control group was just taught the standard language arts program. It was noticed that the experimental group outperformed the standard group evidenced in improved lexical knowledge and reading comprehension. The exposition to direct lexis instruction aided the control group to be more aware of the context as a source of information to grasp meaning. The study concluded that direct lexical instruction seems to produce positive results, especially with students with low lexical and reading comprehension levels.

In the third study by Burrows and Holsworth (2016) with 151 Japanese college students in an English reading class, the objective was to train them to recognize frequent words. The researchers selected fifty target words from two reading texts. This word list was split into two equal halves based on the frequency of the words. These students were separated in five groups regarding the emphasis to be taught: control, semantic, orthographic, orthographic/semantic, and orthographic/semantic/phonological. Each one of these groups was assigned a specific task and tested at the beginning and at the end of each training session. This experiment lasted 8 weeks. The control group was given a reading practice with a written text without word recognition. The semantic one focused on the word meaning and had to write sentences using the words from the list. Within the orthographic group, the emphasis was made on spelling. The orthographic/semantic group carried out spelling and meaning processing activities. The orthographic/semantic/phonological group concentrated on more word recognition. The researchers concluded that the target group with more word recognition components outperformed the others and their reading comprehension boosted.

As noticed, direct lexis instruction has a positive effect on lexis development and students' reading performance. In fact, direct instruction seems to be one of the most effective methods to make learners build up lexis in different contexts considering the number of lexical items to learn. In addition, direct instructions should provide encounters with the lexical items to help learners internalize the meaning in diverse contexts. In line with it, Marzano (2009) proposed three-stage phases to teach lexis directly: "(1) an introductory phase, (2) a comparison phase, and (3) a review and refinement phase" (p. 23). The first one centers on making learners associate the new lexical item with an existing one. The second attempts to help them distinguish items regarding their meaning, in relation to items of 
the same kind. Finally, the third stage enhances learners' understanding by connecting lexical items. By implementing direct instruction, teachers can contribute to extending students' lexical development with an incidence in their reading comprehension.

\subsection{Lexical Knowledge (Breadth and Depth)}

The findings have evidenced a strong link between reading comprehension and lexical knowledge. In Sedita's words (2005), lexical knowledge (LK) "is crucial to reading comprehension and determines how well students will be able to comprehend the texts they will read..." (p. 1). LK is usually classified into breadth and depth. Qian (2002) defines breadth of lexical knowledge as "the number of words the meaning of which one has at least some superficial knowledge" (p. 515) and depth of lexical knowledge as "how well one knows a word" (p. 515). As Perfetti (2007) puts it, breadth of lexical knowledge has been labeled as a predictor of success for reading. In consequence, these two aspects of lexical are interconnected and play a prominent role in effective reading comprehension. Four of the studies illustrate this aspect.

Firstly, Qian (2002) framed in a TOEFL 2000 investigation aimed at finding out the roles that lexical knowledge (breadth and depth: synonymy, polysemy, and collocation) plays in performance in standardized tests and the relationship with reading comprehension levels. The subjects were 217 ESL students at a university context. Four different tests were administered to them: depth-of-vocabulary-knowledge (DVK), vocabulary levels test, TOEFL vocabulary item measure (TOEFL-VIM) and TOEFL reading for basic comprehension measure (TOEFL-RBC). The results evidenced that these tests can predict the degree of reading performance these students can achieve. Based on this, he concluded that lexical knowledge plays an important role in the prediction of reading comprehension.

Secondly, Kameli and Bin Bakin (2013) wanted to demonstrate the impact of lexical knowledge on reading comprehension performance in EFL learners through the use of Vocabulary Level Test-VLT and IELTS at a language institute. The subjects were 220 Iranian adult students with advanced English level and different academic levels. They were given the same questionnaire and the VLT to measure the breadth/size of lexical knowledge (the University Word List-UWL was eliminated from the package). Afterwards, their reading comprehension was tested through an academic reading section of IELTS. To have the statistical analysis of both tests, Statistical Package for Social Sciences (SPSS) was used. The results showed that there is a positive correlation between the learners' lexical knowledge breadth/size and the reading comprehension performance. In conclusion, these researchers proved the assumption that lexical knowledge of breadth/size can impact reading comprehension thoroughly.

Thirdly, Duff et al. (2015) performed a study where a group of L1 485 students (4th, 8th and 10th grade) was assigned tasks and administered tests. The aim was to demonstrate the effectiveness of the Mathew Effects, which consists of individual differences in reading skills. The results showed that there is a close relationship between the reading exposure and the lexis growth. The authors also claimed that the text type (mostly narratives) along with the exposure to wide-ranging lexis helps learners expand their lexis gradually throughout the school years. In addition, the findings support that reading is relevant to the lexis process acquisition in school children and teenagers.

Finally, Binder et al. (2017) tried to establish how lexical breadth and depth are closely related to reading comprehension. To prove that, 107 female college students aged 18-40 were assigned tasks and given tests to assess their lexical knowledge. For breadth, the target group was asked to write diverse forms of a root word using prefixes and suffixes. The researchers also had them complete a set of six sentences with the corresponding missing word. For depth, the subjects were tested through a standardized reading comprehension and lexis test. This study demonstrated that knowing a great number of lexical items in varied contexts is necessary for reading comprehension and reading speed.

As seen, the lexical knowledge is important to develop lexical competence and improving reading comprehension. Due to this, tasks to develop lexical knowledge should be implemented by language teachers to expand the component beyond spelling and meaning. Knowing a lexical unit entails a more multidimensional approach including the use of collocations, constraints and grammatical functions. Including opportunities for learners to have profound knowledge of words as used in different contexts will help reading and communication.

\subsection{Incidental and Intentional Learning}

The relationship between incidental and intentional lexical acquisition is relevant to reading. Hulstijn (2001) defines incidental lexis learning as "the byproduct of any activity not explicitly geared to vocabulary learning..." (p. 271). Ellis (2008) refers to intentional learning as explicit knowledge, which "is conscious, declarative, 
anomalous, and inconsistent (...) and is only accessible through controlled processing in planned language use. It is verbalizable, in which case it entails semi-technical or technical metalanguage...” (pp. 6-7). The following four studies deal with these aspects.

Rashidi and Adivini (2010) did some research on the correlation between lexis learning and the reading of short stories in 40 Iranian EFL learners. The target group was divided into two. The control group was assigned to read the stories just for comprehension purposes whereas the experimental group was also taught directly some previously selected words. The outcomes of the experimental group were better in terms of incidental lexis expansion through reading. These students paid more attention to the contextual clues to guess the meaning of unknown words than the control group, who was just provided the meaning of a selected list of words. Both groups were unaware of a follow-up lexis test. These authors affirmed that incidental lexis learning can improve lexis development in the long run.

Ponniah (2011) conducted a study to analyze the performance of 49 first-year adult ESL students in an Indian University. Learners were divided into two groups: 26 in the experimental group and 23 in the comparison group. As a pretest, participants from both groups 1) wrote the dictionary meaning of 20 words from the story and, 2) used the 20 words to write sentences. Then, the experimental group read a story that was edited for comprehensibility and the comparison group learned the dictionary meanings of 51 unfamiliar words. As a posttest, participants from both groups repeated the two tasks from the pretest. Results of the pre and posttest confirm that learners who read were able to use the subconsciously acquired words in sentences, whereas the participants that learned the dictionary meaning of words could not use them in sentences.

Alavi and Keyvanshekouh (2012) conducted a study with a group of thirty-eight EFL college Iranian students who were split into two groups. Twenty of them utilized the tool "Moodle reader" (data base containing online quizzes based on graded readers) to complement their extensive reading (ER) program and eighteen continued with the traditional ER program. The researchers wanted to find out whether the implementation of the Moodle reader could have a positive effect on incidental lexis growth and on the lexis knowledge (recognition and production). To do that, the researchers administered production and recognition lexis level tests to both groups prior and subsequent to the experiment. As a result, the experimental group had higher incidental and production lexical gains; the lexical recognition remained slightly the same for both groups. The findings evidenced the strong relationship between extensive reading through the Moodle reader and the incidental lexis development.

Liu (2017) worked with 103 Chinese college students to prove the strong influence that reading has on incidental lexis acquisition. The researcher used a reading passage containing gloss annotations in English, Chinese and Chinese and English. 18 target words were identified and replaced by nonsense words. These were glossed equally in the three languages. The students were divided in three groups: one pilot composed of 35 and the other groups of 68 students each. The pilot group was tested with the original words. On the contrary, the largest group was administered two formal tests: reading and the breadth of vocabulary knowledge. These tests contained the 18 replaced words. The researcher concluded that the most effective method in retention to enhance incidental lexis acquisition through reading was that of word glossing in both Chinese and English.

The difficulties that learners face in reading comprehension in the language classrooms have been related to their limited lexical knowledge. Hirsch (2003) expressed that an adept reader knows between $90 \%$ and $95 \%$ of the lexical items and when readers have lower percentages, they have comprehension problems. For this reason, teachers should be aware of how incidental and intentional learning work together for lexis growth and lifelong learning and incorporate practice activities into their classrooms to tackle both types of lexical learning. Extensive reading has been found to be effective in helping learners expand their incidental lexical knowledge.

\subsection{Receptive and Productive Lexical Knowledge}

Receptive and productive lexical knowledge complement each other and support reading comprehension. Nation (2001) defines receptive knowledge as "perceiving the form of a word while listing or reading and retrieving its meaning" (pp. 24-25). He also refers to productive knowledge as "wanting to express a meaning through speaking or writing and retrieving and producing the appropriate spoken or written word form" (p. 25). When the lexical items are worked systematically in class, there is a greater chance for learners to strengthen these two dimensions and expand their lexis for gains in text comprehension. This can be seen in the study below.

Payá-Guerrero and Esteban-Segura (2015) wanted to prove whether narrow reading or reading plus vocabulary-enhancement activities could be more effective to acquire lexis. The subjects were two EFL groups with a basic level of English as evidenced by an English test. The first group had 21 students ( 8 of them were repeating the school year) and the second group, 14 students ( 8 of them repeating the year as well). The first group received the narrow reading (NR) experiment and the second group the reading plus vocabulary-enhancement 
activities (RV). They were given 55 minute-classes three times a week during six weeks with the same seasoned teacher.

In week one, 20 words were chosen to be taught from two distinct texts (both groups). They were tested using a pretest (without formal instruction) and a post-test (with formal instruction). The tests were taken and adapted from the Vocabulary Knowledge Scale laid out by Paribakht and Wesche (1997). In week two, the target groups read the first main text passage containing the 20 -words in boldface. Then, the teacher conducted a discussion. Afterwards, the students answered five reading comprehension questions. The outcomes of the activities in terms of proficiency were almost the same. In week three, the NR group was assigned a text passage having the same 20 words with the incidental learning method. To the contrary, the RV group was asked to do a more profound activity with the selected lexical items with the intentional method. In the remaining weeks, they followed the same pattern as in week 3.

The researchers found that both groups NR and RV had positive effects on their lexis development. However, the gains of the RV group were greater than those of the NR. In relation to the receptive and productive lexical knowledge, the performance of the NR students was superior in their receptive knowledge, but the performance of the RV group was much more effective for the productive knowledge thanks to the numerous activities.

Drawing from this study, learning about how to balance receptive and productive lexical knowledge tasks into the language classroom seem to be relevant for teachers given the impact that both type of knowledge have in students' lexical development and in consequence in their reading performance. Regardless of the teacher instructional approach, time should be devoted to explicitly addressing tasks to help students develop receptive and productive knowledge harmoniously. In doing so, they can assist learners in enhancing lexis so that they can excel in reading.

\section{Conclusion}

The objective that guided this review was to demonstrate with empirical data the connection between lexical development and reading comprehension to supports teachers' intuitive beliefs about this relationship. To attain that, a wide range of research studies were screened and analyzed using some pre-established criteria (see methodology). In the end, just 13 of them were selected. These studies were conducted in different educational contexts and with varied target groups. Some salient categories emerged from the analysis such as lexical coverage, direct instruction, lexical knowledge, incidental and intentional learning as well as receptive and productive lexical knowledge also found in previous studies (Bogaards \& Laufer, 2004; Maiguashca, 1993). The outcome of the analysis of each of these studies showed that there is a strong link between lexical development and reading comprehension. It was interesting to find that, in studies published between 2016 and 2017, there seems to be an interest in providing guidelines or models to the academic community of lexis development through reading. In this review, we have ratified what Pigadia and Schmitt stressed in 2006 "A number of studies during the last two decades have confirmed the widespread belief that second language learners can acquire vocabulary through reading" (p. 1). From the studies, it is possible to derive issues to be considered for further reflection and research 1) the importance of lexical direct instruction and the need of models that respond to contextual characteristics of the teacher, learners and learning scenarios; 2) instructional tasks and research designs that tap on lexical breadth and depth; 3) research informed guidelines that suggest coherent, systematic and pedagogically sound lexical principles to EFL teachers who are ultimately in charge of curricular design at their institutions. The focus on lexical research can have ample implications for the development of reading as well as for the development of other language competences and abilities.

\section{Acknowledgment}

This review has been made as a part of the work in the Doctoral degree in Education at Universidad Del Norte.

\section{References}

Alavi, S., \& Keyvanshekouh, A. (2012). Using the Moodlereader as an extensive reading tool and its effect on Iranian EFL students' incidental vocabulary learning. English Language Teaching, 5(6), 135-145. https://doi.org/10.5539/elt.v5n6p135

Alemi, M., \& Tayebi, A. (2011). The influence of incidental and intentional vocabulary acquisition and vocabulary strategy use on learning L2 vocabularies. Journal of Language Teaching and Research, 2(1), 81-98. https://doi.org/10.4304/jltr.2.1.81-98

Anderson, R., \& Freebody, P. (1981). Vocabulary and knowledge. In J. T. Gutrie (Ed.), Comprehension and teaching: Research review (pp. 77-117). Newark, DE: International Reading Assn.

Apthorp, H., Randel, B., Cherasaro, T., Clark, T., McKeown, M., \& Beck, I. (2012). Effects of a supplemental 
vocabulary program on word knowledge and passage comprehension. Journal of Research on Educational Effectiveness, 5(2), 160-188. https://doi.org/10.1080/19345747.2012.660240

Arnaud, P., \& Béjoint, H. (Eds.). (1992). Vocabulary and Applied Linguistics. Basingstoke: Macmillan. https://doi.org/10.1007/978-1-349-12396-4

Bancroft, J. (2004). Second language vocabulary acquisition: a lexical input approach. Foreign Language Annals, 200-208. https://doi.org/10.1111/j.1944-9720.2004.tb02193.x

Baumann, J. F., Edwards, E. C., Font, G., Tereshinski, C. A., Kame'enui, E. J., \& Olejnik, S. (2002). Teaching morphemic and contextual analysis to fifth-grade students. Reading Research Quarterly, 37(2), 150-176. https://doi.org/10.1598/RRQ.37.2.3

Binder, K. S., Cote, N. G., Lee, C., Bessette, E., \& Vu, H. (2017). Beyond breadth: the contributions of vocabulary depth to reading comprehension among skilled readers. Journal of Research in Reading, 40(3), 333-343. https://doi.org/10.1111/1467-9817.12069

Blachowicz, C., Fisher, P., Ogle, D., \& Watts-Taffe, S. (2006). Theory and research into practice vocabulary: questions from the classroom. Reading Research Quarterly, 41(4), 524-539. https://doi.org/10.1598/RRQ. 41.4.5

Bogaards, P., \& Laufer, B. (Eds.). (2004). Vocabulary in a second language: selection, acquisition and testing. Amsterdam, the Netherlands: Benjamins. https://doi.org/10.1075/11lt.10

Burrows, L., \& Holsworth, M. (2016). The Effects of Explicit Word Recognition Training on Japanese EFL Learners. The Reading Matrix: An International Online Journal, 16(2), 81-97.

Carter, R., \& McCarthy, M. (Eds.). (1988). Vocabulary and language teaching. London: Longman.

Caro, K., \& Rosado, N. (2017). Lexis, lexical competence and lexical knowledge: a review. Journal of Language Teaching and Research, 8(2), 205-213. https://doi.org/10.17507/jltr.0802.01

Carver, R. (1994). Percentage of unknown vocabulary words in text as a function of the relative difficulty of the text: implications for instruction. Journal of Reading Behaviour, 26(4), 413-437. https://doi.org/10.1080/ 10862969409547861

Chall, J., \& Jacobs, V. (2003). Poor children's fourth-grade slump. American Educators, 27(1), 14-17.

Chamot, A. (1987). The learning strategies of ESL students‘. In A. Wenden, \& J. Rubin (Eds.), Learning Strategies in Language Learning (pp.71-83). New Jersey, Prentice Hall.

Davis, F. (1968). Research on comprehension in reading. Reading Research Quarterly, 7, 628-678. https://doi.org/10.2307/747108

Davis, F. (1944). Fundamental factors of comprehension in reading. Psychometrika, 9, 185-197. https://doi.org/10.1007/BF02288722

DeCarrico, J. (2001). Vocabulary learning and teaching. In M. Celce-Murcia (Ed.), Teaching English as a second or foreign language (3rd ed., pp. 285-299). Boston: Heinle.

Duff, G., Tomblin, B., \& Catts, H. (2015). The influence of reading on vocabulary growth: A case study for a Matthew effect. Journal of Speech, Language and Hearing Research, 58, 853-864. https://doi.org/10.1044/ 2015_JSLHR-L-13-0310

Ellis, G., \& Sinclair, B. (1989). Learning to learn English. Cambridge: Cambridge University Press.

Ellis, R. (2008). Investigating grammatical difficulty in second language learning: implications for second language acquisition research and language testing. International Journal of Applied Linguistics, 18(1), 4-22. https://doi.org/10.1111/j.1473-4192.2008.00184.x

Farhady, H. (2006). Twenty-five years of living with applied linguistics: collocation of articles. Iran, Teheran: Rahama press.

Folse, K. (2004). Vocabulary myths. Ann Arbor, MI: University of Michigan Press. https://doi.org/10.3998/mpub.23925

Graves, M. (2000). A vocabulary program to complement and bolster a middle-grade comprehension program. In B. M. Taylor, M. F. Graves, \& P. van den Broek (Eds.). Reading for meaning: Fostering comprehension in the middle grades (pp. 116-135). Newark, DE: International Reading Association.

Groux, D. (2015). Education and development: the contribution of comparative education. In D. Mathenson (Ed.), 
An introduction to the study of education. New York: David Fulton Book, Routledge.

Hirsch, E. (2003). Reading Comprehension Requires Knowledge - of Words and the World: Scientific Insights into the Fourth-Grade Slump and the Nation's Stagnant Comprehension Scores. American Educator, 27(1), $10-29$.

Hu, M., \& Nation, P. (2000). Unknown vocabulary density and reading comprehension. Reading in a Foreign Language, 13, 403-430.

Hunt, A., \& Beglar, D. (1998). Current research and practice in teaching vocabulary. The Language Teacher, 22(1), $7-10$.

Hulstijn, J. (2003). Incidental and intentional learning. In C. Doughty, \& M. H. Long (Eds.). The handbook of second language acquisition (pp. 349-381). Oxford: Blackwell. https://doi.org/10.1002/9780470756 492.ch12

Hulstijn, J. (2001). Intentional and incidental second language vocabulary learning: A reappraisal of elaboration, rehearsal and automaticity. In P. Robinson (Ed.), Cognition and second language instruction. Cambridge, UK: Cambridge University Press. https://doi.org/10.1017/CBO9781139524780.011

Jiménez, R. (2002). El concepto de competencia léxica en los estudios de aprendizaje y enseñanza de segundas lenguas. Atlantis, 24(1), 149-162.

Jiménez, R. (2003). Sex differences in L2 vocabulary learning strategies. International Journal of Applied Linguistics, 13(1), 54-77. https://doi.org/10.1111/1473-4192.00037

Joshi, R. (2005). Vocabulary: a critical component of comprehension. Reading \& Writing Quarterly, 21, 209-219. https://doi.org/10.1080/10573560590949278

Kameli, S., \& Bin Baki, R. (2013). The Impact of Vocabulary Knowledge Level on EFL Reading Comprehension. International Journal of Applied Linguistics \& English Literature, 2(1), 555-563. https://doi.org/10.7575/ ijalel.v.2n.1p.85

Ketabi, S., \& Hashemi, S. (2011). Vocabulary in the approaches to language teaching: from the twentieth century to the twenty-first. Journal of Language Teaching and Research, 2(3), 726-731. https://doi.org/10.4304/ jltr.2.3.726-731

Krashen, S. (2013). Reading and vocabulary acquisition: supporting evidence and some objections. Iranian Journal of Language Teaching Research, 1(1), 27-43.

Laufer, B. (1989). What percentage of text-lexis is essential for comprehension? In C. Lauren, \& M. Nordman (Eds.), Special language: From humans thinking to thinking machines. Clevedon, UK: Multilingual Matters, Ltd.

Laufer, B. (1991). How much lexis is necessary for reading comprehension? In P. J. L. Arnaud, \& H. Bejoint (Eds.), Vocabulary and applied linguistics (pp. 126-132). Basingstoke: Macmillan.

Laufer, B. (1992). How much lexis is necessary for reading comprehension? In H. Bejoint, \& P. Arnaud (Eds.), Vocabulary and applied linguistics (pp. 126-132). London: Macmillan. https://doi.org/10.1007/978 -1-349-12396-4_12

Liu, S. (2017). An Experimental Research on the Effects of Types of Glossing on Incidental Vocabulary Acquisition through Reading. Journal of Language Teaching and Research, 8(4), 782-793. https://doi.org/10.17507/jltr.0804.19

Maiguashca, R. (1993). Teaching and learning vocabulary in a second language: past, present, and future directions. The Canadian Modern Language Review, 50(1), 83-100. https://doi.org/10.3138/cmlr.50.1.83

Manyak, P., \& Bauer, E. (2009). English vocabulary instruction for English learners. The Reading Teacher, 63(2), 174-176. https://doi.org/10.1598/RT.63.2.11

Manyak, P., Gunten, H, Autenrieth, D, Gillis, C, Mastre-O'Farrell, J, Irvine-McDermott, E, Baumann, J, \& Blachowicz, C. (2014). Four practical principles for enhancing vocabulary instruction. Reading Teacher, 68(1), 13-23. https://doi.org/10.1002/trtr.1299

Marzban, A., \& Hadipour, R. (2012). Depth versus breadth of vocabulary knowledge: assessing their roles in Iranian intermediate EFL students' lexical inferencing success through reading. Procedia - Social and Behavioral Sciences, 46, 5296-5300. https://doi.org/10.1016/j.sbspro.2012.06.426

Marzano, R. (2009). Teaching Basic and Advanced Vocabulary: A Framework for Direct Instruction. Boston, MA: 
Heinle/Association for Supervision and Curriculum.

Matsuoka, W., \& Hirsch, D. (2010). Vocabulary learning through reading: Does an ELT course book provide good opportunities? Reading in a Foreign Language, 22, 56-70.

Moir, J., \& Nation, P. (2008). Vocabulary and good language learners. Lessons from good language learners. Cambridge: Cambridge University Press. https://doi.org/10.1017/CBO9780511497667.015

National Reading Technical Assistance Center. (2010). A Review of the Current Research on Vocabulary Instruction. U.S. Department of Education Contract No. ED-08-CO-0123 with RMC Research Corporation.

Nation, P. (2001). Learning Vocabulary in Another Language. Cambridge: Cambridge University Press. https://doi.org/10.1017/CBO9781139524759

Nation, P. (1990). Teaching and learning vocabulary. New York: Newbury House.

Oxford, R. (1990). Language learning strategies. Boston: Heinle \& Heinle Publishers.

Paribakht, T. S., \& Wesche, M. (1997). Vocabulary Enhancement Activities and Reading for Meaning in Second Language Vocabulary Acquisition. In J. Coady, \& T. Huckin (Eds.), Second Language Vocabulary Acquisition: A Rationale for Pedagogy (pp. 174-199). Cambridge: Cambridge University Press.

Payá-Guerrero, M., \& Esteban-Segura, L. (2015). EFL Vocabulary Acquisition: narrow reading versus reading plus vocabulary-enhancement activities. A case study with Spanish secondary school students. Porta Linguarium, 24, 93-105.

Pigada, M., \& Schmitt, N. (2006). Vocabulary acquisition from extensive reading: A case study. Reading in a Foreign Language, 18(1), 1-28.

Prichard, C., \& Matsumoto, Y. (2011). The Effect of Lexical Coverage and Dictionary Use on L2 Reading Comprehension. The Reading Matrix, 11(3), 207-225.

Perfetti, C. (2007). Reading ability: Lexical quality to comprehension, Scientific Studies of Reading, 11, 357-83. https://doi.org/10.1080/10888430701530730

Ponniah, R. J. (2011). Incidental acquisition of vocabulary by reading. The Reading Matrix, 11(2), 135-139.

Qian, D. (2002). Investigating the relationship between vocabulary knowledge and academic reading performance: an assessment perspective. Language Learning, 52(3), 513-536. https://doi.org/10.1111/1467-9922.00193

Rashidi, N., \& Adivi, A. G. (2010). Incidental vocabulary learning through comprehension-focused reading of short stories. Journal of English Language Teaching and Learning, 53(217), 111-129.

Read, J. (2000). Assessing vocabulary. Cambridge: Cambridge University Press. https://doi.org/10.1017/ CBO9780511732942

Ricketts, J., Nation, K., \& Bishop, D. (2007). Vocabulary is important for some, but not all reading skills. Scientific Studies of Reading, 11(3), 235-257. https://doi.org/10.1080/10888430701344306

Ron, J., \& Stage, S. (2007). Fostering the development of vocabulary knowledge and reading comprehension through contextually-based multiple meaning vocabulary instruction. Education and Treatment of Children, 30(1), 1-22. https://doi.org/10.1353/etc.2007.0003

Sedita, J. (2005). Effective vocabulary instruction. Insights on Learning Disabilities, 2(1), 33-45.

Shen, Z. (2008). The roles of depth and breadth of vocabulary knowledge in EFL reading performance. Asian Social Science, 4(12), 135-137.

Shen, W. (2003). Current trends of vocabulary teaching and learning strategies for EFL settings. Feng Chia Journal of Humanities and Social Sciences, 7,187-224.

Schmitt, N., Jiang, X., \& Grabe, W. (2011). The percentage of words known in a text and reading comprehension. The Modern Language Journal, 95, 26-43. https://doi.org/10.1111/j.1540-4781.2011.01146.x

Schmitt, N. (1997). Vocabulary learning strategies. In N. Schmitt, \& M. McCarthy (Eds.), Vocabulary: description, acquisition and pedagogy. Cambridge: Cambridge University Press.

Schoonen, R., Hulstijn, J., \& Bossers, B. (1998). Metacognitive and language-specific knowledge in native and foreign language reading comprehension. An empirical study among Dutch students in grades 6, 8 and 10 . Language Learning, 48(1), 71-106. https://doi.org/10.1111/1467-9922.00033

Sprenger, M. (2013). Teaching the critical vocabulary of the common core. 55 words that make or break students 
understanding. ASCD. Alexandria, Virginia-USA.

Stahl, S. (1983). Differential knowledge and reading comprehension. Journal of Reading Behavior, 15, 33-50. https://doi.org/10.1080/10862968309547495

Texas Reading Initiative (2002). Promoting vocabulary development: Components of effective vocabulary instruction (Revised edition). Austin, TX: Texas Education Agency.

Terman, L. (1916). The measurement of intelligence. Boston: Houghton Mifflin. https://doi.org/10.1037/ 10014-000

Waring, R., \& Takaki, M. (2003). At what rate do learners learn and retain new vocabulary from reading a graded reader? Reading in a Foreign Language, 15(2), 130-163.

West, M. (1926). Learning to read a foreign language. London: Longmans, Green \& Company.

Zhang, L., \& Anual, S. (2008). The role of vocabulary in reading comprehension: the case of secondary school students learning English in Singapore. RELC Journal, 39(1), 51-76. https://doi.org/10.1177/00336 88208091140

Zimmerman, C. (1997). Historical trends in second language vocabulary instruction. In J. Coady, \& T. Huckin (Eds.), Second language vocabulary acquisition (pp. 5-19). Cambridge: Cambridge University Press.

\section{Copyrights}

Copyright for this article is retained by the author(s), with first publication rights granted to the journal.

This is an open-access article distributed under the terms and conditions of the Creative Commons Attribution license (http://creativecommons.org/licenses/by/4.0/). 